\title{
Prospek Pengembangan Padi Gogo Mendukung Lumbung Pangan di Wilayah Perbatasan Pulau Morotai
}

\author{
Upland Rice Development Prospects to Support Food Barns in Morotai Island Border Area
}

\author{
Yopi Saleh $^{1}$, Winda Zainiyah ${ }^{2}$, Ika Ferry Yunianti ${ }^{3}$ \\ ${ }^{1}$ Balai Pengkajian Teknologi Pertanian Jakarta \\ ${ }^{2}$ Balai Pengkajian Teknologi Pertanian Maluku Utara \\ ${ }^{3}$ Balai Penelitian Lingkungan Pertanian
}

\begin{tabular}{l} 
ARTICLE INFO \\
\hline Article history: \\
DOI: \\
$\underline{10.30595 / p s p f s . v 2 i .182}$
\end{tabular}

Submitted:

July 29,2021

Accepted:

Sept 10, 2021

Published:

Nov 10, 2021

Keywords:

Border Region, Food Barns, Upland Rice

\begin{abstract}
Upland rice commodity is generally the second choice after paddy in fulfilling community rice needs. Morotai Island is one of the government's target locations in initiating the Export-Oriented Food Storage program in the Border Region. This study aimed to determined the prospects for the development of upland rice to support food barns in the border region of Morotai Island. The method used is descriptive analysis, measuring the growth rate of rice based on the Compound Annual Growth Rate (CAGR), and measuring the feasibility of farming using income analysis, $\mathrm{R} / \mathrm{C}$ ratio, and break-even point analysis. The results showed that the increase in the growth rate of harvested area and upland rice production was 25,75 percent with a contribution of 42,81 percent and 31,65 percent, recpectively, of the harvested area and rice production on Morotai Island in the 2011 to 2017 period. Upland rice farming has an $\mathrm{R} / \mathrm{C}$ ratio of 1.72 which indicated that this farming is feasible. The potential and opportunities for upland rice development to support food barns on Morotai Island are still very prospective. The development of upland rice can be pursued through intensification and extensification of agriculture with the application of cultivation technology, the use of new high yield varieties, increasing the cropping index, and sustainable soil and water conservation efforts. This needs to be supported by strong farmer and extention institutions and easy access for farmers to finance agriculture.
\end{abstract}

This work is licensed under a Creative Commons Attribution 4.0 International License.

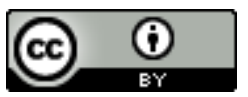

Corresponding Author:

Yopi Saleh

Balai Pengkajian Teknologi Pertanian Jakarta

Email: yopisaleh@gmail.com

\section{PENDAHULUAN}

Pengembangan wilayah perbatasan suatu negara merupakan bagian tidak terpisahkan dari pembangunan nasional. Visi baru pengembangan wilayah perbatasan adalah menerapkan tiga pendekatan sekaligus, yaitu keamanan (security), kesejahteraan (prosperity), dan pelestarian lingkungan (environment sustainabiliy) (Cristanto dkk., 2014; Sulaiman dkk., 2018). Wilayah perbatasan identik dengan daerah perdesaan, daerah pinggiran, daerah tertinggal, atau daerah miskin yang cenderung termarginalkan (Budianta, 2010). (Marwasta, 2016) menambahkan, kawasan perbatasan memiliki permasalahan sosial ekonomi daerah yang kurang berkembang (terbelakang), karena lokasi yang terisolasi/terpencil dengan tingkat aksesibilitas yang rendah. Selain itu, isu pokok ketahanan pangan di kawasan perbatasan juga perlu menjadi perhatian utama mengingat 
produktivitas pertanian relatif rendah, infrastruktur dan sarana-prasarana produksi dan distribusi masih terbatas, kecukupan pangan yang belum memadai (Syarief dkk., 2014), serta membutuhkan inovasi (teknologi) dan dukungan kebijakan "khusus" dan "tematik" (Sulaiman et al., 2018).

Wilayah perbatasan di Indonesia memiliki potensi sumber daya pertanian dan keragaman biofisik untuk dijadikan lumbung pangan daerah. Pemilihan daerah perbatasan sebagai lokasi prospektif untuk pengembangan awal lumbung pangan dunia menjadi tepat dan strategis atas dasar bahwa sebagian besar dari 41 kabupaten wilayah perbatasan memiliki potensi untuk pengembangan kawasan pangan yang secara geopolitis sangat strategis. (Sulaiman et al., 2017). Pengembangan sistem cadangan pangan penduduk pada daerah rawan pangan yang mempunyai kendala aksesibilitas terhadap pangan, secara otomatis telah menumbuhkan lumbung pangan secara tradisional (Rachmat dkk., 2011). Peran dan fungsi lumbung pangan ditujukan untuk menjamin ketersediaan pangan masyarakat dan kemudahan untuk diakses sehingga kebutuhan dasar masyarakat yaitu pangan dapat terpenuhi. Program "Membangun Indonesia dari Pinggiran" adalah refleksi dari kebijakan pemerintah dalam program Nawacita yang dimulai sejak tahun 2014. Pada sektor pertanian, pembangunan kawasan perbatasan diawali dengan menginisiasi Lumbung Pangan Berorientasi Ekspor di Wilayah Perbatasan (LPBE-WP) mewujudkan “Indonesia Menuju Lumbung Pangan Dunia 2045” (Sulaiman et al., 2018).

Pulau Morotai merupakan salah satu wilayah terluar negara Indonesia yang terletak antara Laut Maluku dan Samudera Pasifik serta berbatasan dengan negara Philipina. Konsumsi pangan penduduk Pulau Morotai masih bergantung pada ketersediaan beras sebagai kebutuhan pangan pokok. Produksi pangan di Pulau Morotai khususnya beras ini dihasilkan dari produksi padi sawah dan padi gogo. Produksi padi gogo terbesar di Pulau Morotai terjadi pada tahun 2016 sebesar 2.853 ton per tahun atau menyumbang sebesar $41,34 \%$ dari produksi padi total di Pulau Morotai (BPS Kabupaten Pulau Morotai, 2017). Kontribusi ini sangat besar jika dibandingkan dengan kontribusi produksi padi gogo di Maluku Utara dan nasional di tahun yang sama yaitu masing-masing sebesar 26,91\% (BPS Provinsi Maluku Utara, 2017) dan 4,66\% (Kementerian Pertanian, 2018). Hal ini menjadikan komoditas padi gogo di Pulau Morotai memiliki peran sebagai salah satu sumber pangan utama untuk cadangan pangan masyarakat yang bisa diandalkan untuk memenuhi kebutuhan konsumsi. Salah satu keuntungan spesifik padi gogo adalah hasil panennya dapat berguna sebagai cadangan ketahanan pangan regional, pada waktu stok beras di pasaran berkurang (Sumarno dan Hidayat, 2007). Oleh karena itu, pengembangan padi gogo dapat berkontribusi mendukung terwujudnya lumbung pangan di wilayah perbatasan.

Penelitian ini bertujuan untuk mengetahui prospek pengembangan padi gogo mendukung lumbung pangan di wilayah perbatasan Pulau Morotai. Uraian dalam makalah ini dapat dijadikan sebagai bahan masukan bagi pengambil kebijakan untuk pembangunan pertanian, sehingga pengembangan produksi padi gogo lebih menjadi perhatian.

\section{METODE PENELITIAN}

Penelitian ini dilaksanakan pada bulan Agustus-Oktober 2017. Lokasi penelitian terpilih adalah Kecamatan Morotai Timur, Kabupaten Pulau Morotai yang ditentukan secara sengaja (purposive sampling) karena Pulau Morotai adalah salah satu wilayah perbatasan yang ada di Indonesia. Penelitian ini menggunakan data primer dan sekunder.

Data primer dalam penelitian didapatkan dengan survei dan wawancara terhadap 30 orang petani padi gogo, Dinas Pertanian dan Penyuluh Pertanian Lapangan (PPL) untuk mengetahui informasi dan data keragaan usahatani serta upaya dan program pengembangan padi gogo di Pulau Morotai menggunakan kuisioner. Untuk menghitung pendapatan usahatani dapat menggunakan rumus sebagai berikut (Normansyah dkk., 2014):

$\pi$ tunai $=N P-B T$
$\pi$ total $=N P-(B T+B D)$

Dimana $\boldsymbol{\pi}$ adalah pendapatan (Rp), NP adalah penerimaan tunai (Rp), BT adalah biaya tunai (Rp), dan BD adalah biaya diperhitungkan (Rp). Tingkat kelayakan usahatani dapat diketahui dengan menghitung $\mathrm{R} / \mathrm{C}$ ratio (Soekartawi, 1995). R/C ratio adalah perbandingan antara jumlah penerimaan dan jumlah pengeluaran usahatani. Perhitungannya menggunakan persamaan:

$R /{ }_{C}$ ratio $=\frac{\text { Jumlah Penerimaan }}{\text { Jumlah Pengeluaran }}$

Dimana jika $\mathrm{R} / \mathrm{C}$ ratio $>1$ maka usahatani menguntungkan (layak dikembangkan), $\mathrm{R} / \mathrm{C}$ ratio $=1$ maka usahatani impas, dan $\mathrm{R} / \mathrm{C}$ ratio $<1$ maka usahatani rugi (tidak layak dikembangkan). Analisis titik impas atau break even point (BEP) digunakan untuk mengetahui batas produksi atau harga jual minimum agar petani tidak menderita kerugian tetapi belum memperoleh keuntungan atau keuntungan sama dengan nol. Perhitungan rumus BEP adalah sebagai berikut: 
$B E P$ produksi $=\frac{\text { Total Pengeluaran }}{\text { Harga Jual }}$
BEP harga jual $=\frac{\text { Total Pengeluara }}{\text { Total Produkst }}$

BEP harga jual $=\frac{\text { Total Produksi }}{\text { Tot }}$

Data sekunder diperoleh dari BPS, Dinas Pertanian Kabupaten Pulau Morotai, BPTP Maluku Utara, Kementerian Pertanian, dan sumber data lainnya yang sesuai. Data dianalisis dengan analisis statistik deskriptif menggunakan tabel untuk menjelaskan luas panen, produksi, produktivitas, dan varietas padi gogo, Analisis data kuantitatif menggunakan analisis Compound Annual Growth Rate (CAGR) untuk mengukur laju pertumbuhan produksi padi gogo menggunakan rumus (Leta dkk., 2019):

$$
\operatorname{CAGR}\left(t_{n}, t_{0}\right)=\left(\frac{V\left(t_{n}\right)}{V\left(t_{0}\right)}\right)^{\frac{1}{t_{n}-t_{0}}}-1
$$

Dimana $\mathbf{V}\left(\mathbf{t}_{\mathbf{0}}\right)$ adalah nilai awal, $\mathbf{V}(\mathbf{t n})$ adalah nilai akhir, dan $\mathbf{t}_{\mathbf{n}}-\mathbf{t}_{\mathbf{0}}$ adalah jumlah periode tahun.

\section{HASIL DAN PEMBAHASAN}

\section{Kinerja Produksi Padi Gogo di Pulau Morotai}

Peningkatan luas panen dan produksi padi sawah dan padi gogo terbesar di Pulau Morotai terjadi pada tahun 2016, yaitu luas panen masing-masing sebesar 1.249 ha dan 1.334 ha dan produksi masing-masing sebesar 4.048 ton dan 2.853 ton. Laju pertumbuhan luas lahan dan produksi padi sawah dan padi gogo dalam periode tahun 2011-2017 termasuk pesat dengan pertumbuhan/tahun mencapai lebih dari 25 persen (Tabel 1).

Tabel 1. Luas panen, produksi, produktivitas padi sawah dan padi gogo, serta laju pertumbuhannya di Pulau Morotai periode tahun 2011-2017

\begin{tabular}{ccccccc}
\hline Tahun & $\begin{array}{c}\text { Luas panen } \\
\text { padi sawah } \\
\text { (ha) }\end{array}$ & $\begin{array}{c}\text { Produksi padi } \\
\text { sawah (ton) }\end{array}$ & $\begin{array}{c}\text { Produktivitas } \\
\text { padi sawah } \\
\text { (t/ha) }\end{array}$ & $\begin{array}{c}\text { Luas panen } \\
\text { padi gogo } \\
\text { (ha) }\end{array}$ & $\begin{array}{c}\text { Produksi } \\
\text { padi gogo } \\
\text { (ton) }\end{array}$ & $\begin{array}{c}\text { Produktivitas } \\
\text { padi gogo (t/ha) }\end{array}$ \\
\hline 2011 & 253 & 759 & 3,00 & 108 & 216 & 2,00 \\
2012 & 555 & 1.665 & 3,00 & 399 & 798 & 2,00 \\
2013 & 576 & 1.728 & 3,00 & 601 & 1.130 & 1,88 \\
2014 & 639 & 1.917 & 3,00 & 375 & 750 & 2,00 \\
2015 & 314 & 942 & 3,00 & 206 & 412 & 2,00 \\
2016 & 1.249 & 4.048 & 3,24 & 1.334 & 2.853 & 2,14 \\
2017 & 1.022 & 4.048 & 4,00 & 427 & 854 & 2,00 \\
Rata-rata & 658 & 2.164 & 3,18 & 493 & 1.002 & - \\
Kontribusi & 57,19 & 68,35 & - & 42,81 & 31,65 & 0,0000 \\
$(\%)$ & 0,2620 & 0,3240 & 0,0491 & 0,2575 & 0,2575 & 0,00 \\
CAGR & 26,20 & 32,40 & 4,91 & 25,75 & 25,75 & \\
Pertumbuhan/ta & & & & & & \\
hun (\%) & & & & & &
\end{tabular}

Sumber: BPS Kabupaten Pulau Morotai diolah, 2017 dan 2019.

Salah satu faktor pendorong luas panen dan produksi padi meningkat sangat cepat pada periode tahun 2015-2016 disebabkan adanya program Upaya Khusus Padi, Jagung dan Kedelai (UPSUS PAJALE) yang sangat masif mendorong petani di Pulau Morotai untuk bertanam padi. Hasil penelitian (Juhandi \& Enre, 2019) menunjukkan bahwa terjadi penambahan jumlah provinsi di Indonesia sebagai sentra komoditi padi pasca program UPSUS PAJALE dilaksanakan, dari yang semula 18 provinsi menjadi 19 provinsi. Peningkatan produksi padi di Pulau Morotai ini secara langsung dapat berkontribusi terhadap peningkatan ketahanan pangan di wilayah perbatasan.

Kebutuhan rata-rata konsumsi beras per tahun pada periode 2011-2017 dengan rata-rata jumlah penduduk 58.964 jiwa, dan konsumsi beras per kapita 88 kg/orang/tahun (BPS, 2018) mencapai 5.189 ton/tahun. Sedangkan ketersediaan beras dari hasil produksi padi di Pulau Morotai baru mencapai 2.027 ton/tahun atau sekitar 39,06 persen dari kebutuhan konsumsi beras penduduk. Kontribusi rata-rata produksi padi gogo terhadap produksi padi di Pulau Morotai cukup besar (31,65 persen), hal ini menyebabkan padi gogo memiliki peranan yang penting dalam memenuhi kebutuhan pangan masyarakat. Penerapan teknologi budidaya padi gogo di Pulau Morotai masih sangat sederhana sehingga produktivitasnya rendah, di bawah produktivitas nasional yang sudah mencapai 3,28 t/ha (Kementerian Pertanian, 2018).

Menurut Maulana (2004) terdapat dua faktor yang dapat mempengaruhi produktivitas yaitu kemampuan varietas dalam berproduksi dan kualitas dari usahatani padi. Oleh karena itu produktivitas padi gogo ini masih dapat ditingkatkan melalui introduksi varietas unggul dan penerapan teknologi budidaya Pengelolaan Tanaman 
Terpadu (PTT). Toha (2007) dalam penelitiannya di Desa Rama Murti-Lampung dapat menghasilkan produksi rata-rata sebesar 5,14 t/ha. Fitria dan Ali (2014) dalam penelitiannya di Kabupaten Aceh Besar dapat menghasilkan produksi padi gogo sebesar 5,42-6,26 t/ha dan hasil produksi padi gogo di Balubur LimbanganKabupaten Garut berkisar 3,01-3,83 t/ha (Sujitno \& Kurnia, 2014), sedangkan di Kabupaten Pandeglang-Banten baru dapat mencapai 2,3-3,9 t/ha (Yuniarti, 2015). Pemberian pupuk NPK $300 \mathrm{~kg} / \mathrm{ha}$ dapat meningkatkan hasil tanaman padi gogo dengan hasil GKP tertinggi mencapai 5,78 t/ha (Hasmi \& Widyantoro, 2017), sedangkan perlakuan pemberian pupuk organik pada pertanaman padi gogo memberikan hasil GKP yang semakin tinggi dengan semakin tingginya penggunaan dosis pupuk organik (Sujitno \& Dianawati, 2017).

\section{Keragaan Usahatani Padi Gogo di Pulau Morotai}

Usahatani padi gogo di Pulau Morotai umumnya dilakukan dengan sistem pertanian alami (natural farming), dimana petani masih sangat bergantung pada kemampuan alam dalam usahataninya. Selain itu petani juga masih sangat menjaga dan melestarikan kearifan lokal yang ditinggalkan oleh para leluhur. Usahatani padi gogo dilakukan dengan sistem ladang berpindah dengan luasan sekitar 1-2 ha/petani. Sistem ladang berpindah telah cukup lama dipraktekkan oleh petani zaman dahulu dengan tujuan untuk menjaga kualitas tanah. Ladang berpindah adalah suatu sistem tanam dengan cara merotasi waktu bera hutan dengan tanaman musiman (Rope, 2013). Petani di Pulau Morotai menanam padi gogo sekali dalam setahun, yaitu pada saat awal musim hujan (MH I). Berdasarkan pengalaman selama tiga tahun terakhir, petani akan mulai melakukan pembukaan dan pembersihan lahan pada bulan September sehingga pada bulan Oktober-Desember sudah bisa dilakukan pertanaman. Ketersediaan air selama musim penghujan diharapkan dapat mencukupi kebutuhan air tanaman padi gogo selama semusim. Petani padi gogo Pulau Morotai jarang sekali menggunakan pupuk organik, pupuk anorganik, pestisida, maupun herbisida. Hal ini telah menjadi kebiasan petani secara turun temurun.

Hasil survey pada petani padi gogo, hasil panen per hektarnya rata-rata mencapai sekitar 1,47 ton GKP/ha. Rata-rata produksi padi gogo setara beras di Pulau Morotai sebesar 705,10 kg/ha/MT dengan harga jual beras rata-rata Rp. 11.333, maka petani memperoleh penerimaan dari usahatani padi gogo sebesar Rp. 7.941.335,-. Petani mengeluarkan total biaya produksi sebesar Rp. 4.579.167,-/ha/MT, sehingga pendapatan atas biaya total produksi sebesar Rp. 3.362.168,-/ha/MT. Hasil analisis finansial usahatani padi gogo di Pulau Morotai ditampilkan pada Tabel 2.

Tabel 2. Analisis finansial usahatani padi gogo di Pulau Morotai

\begin{tabular}{clcc}
\hline No & \multicolumn{1}{c}{ Uraian } & Satuan & Jumlah (Rp) \\
\hline 1 & Harga beras & $\mathrm{Rp} / \mathrm{kg}$ & 11.333 \\
2 & Produksi setara beras & $\mathrm{Kg}$ & 705,10 \\
3 & Total biaya produksi & $\mathrm{Rp} / \mathrm{ha}$ & 4.579 .167 \\
4 & Total biaya tunai & $\mathrm{Rp} / \mathrm{ha}$ & 3.187 .500 \\
5 & Penerimaan & $\mathrm{Rp} / \mathrm{ha}$ & 7.941 .335 \\
6 & Pendapatan atas biaya tunai & $\mathrm{Rp} / \mathrm{ha}$ & 4.753 .835 \\
7 & Pendapatan atas biaya total & $\mathrm{Rp} / \mathrm{ha}$ & 3.362 .168 \\
8 & R/C atas biaya tunai & - & 2,49 \\
9 & R/C atas biaya total & - & 1,72 \\
10 & BEP harga beras & $\mathrm{Rp} / \mathrm{kg}$ & $7.168,35$ \\
11 & BEP produksi & $\mathrm{kg}$ & 406,92 \\
\hline
\end{tabular}

Sumber: Analisis data primer, 2017

Kelayakan usahatani padi gogo di Pulau Morotai dapat dilihat melalui perhitungan R/C ratio, yaitu membandingkan penerimaan hasil produksi dengan total biaya produksi yang dikeluarkan selama satu siklus usahatani. Usahatani suatu komoditas dikategorikan layak apabila nilai R/C ratio lebih besar dari satu (nilai R/C $>1$ ). Artinya usahatani tersebut akan semakin menguntungkan jika nilai R/C ratio semakin tinggi (Gray dkk., 1992). Nilai R/C atas biaya total sebesar 1,72 (nilai $\mathrm{R} / \mathrm{C}>1$ ) menunjukkan bahwa usahatani padi gogo menguntungkan dan layak untuk diusahakan. Nilai break even point (BEP) harga dan produksi beras menunjukkan bahwa sepanjang harga dan produksi beras tidak kurang dari Rp. 7.168,35 dan 406,92 kg, maka usahatani padi gogo tidak mengalami kerugian. Biaya produksi, produksi padi, dan harga jual gabah atau beras sangat mempengaruhi pendapatan yang diterima petani. Usaha tani padi gogo yang dilakukan oleh petani di Pulau Morotai dapat memberikan keuntungan bagi petani, hal ini dikarenakan petani masih mengusahakan tanaman padinya secara alami sehingga biaya produksi yang dikeluarkan juga relatif lebih kecil dibandingkan usahatani modern. 


\section{Dukungan Inovasi Teknologi Padi Gogo}

Inovasi teknologi untuk meningkatkan produksi dan produktivitas padi gogo sudah banyak dihasilkan, mulai dari varietas unggul baru (VUB) hingga teknologi budidaya padi gogo. Berikut ini beberapa dukungan inovasi teknologi padi gogo yang bisa dimanfaatkan untuk pengembangan padi gogo di wilayah perbatasan Pulau Morotai:

\section{Varietas Unggul Baru (VUB) Padi Gogo}

Banyak varietas unggul padi gogo telah dihasilkan dan dilepaskan oleh pemerintah melalui Badan Litbang Pertanian, namun sebagian besar petani masih memilih untuk menanam varietas lokal. Hal ini dikarenakan karakteristik varietas unggul yang dihasilkan tidak memenuhi preferensi petani. Oleh karena itu, seleksi varietas padi gogo lokal secara partisipatif untuk menciptakan VUB padi gogo dapat mengakomodir preferensi petani, mempertahankan keanekaragaman genetik padi, serta mempercepat adopsi VUB yang dihasilkan (Hairmansis dkk., 2008).

Menurut Malik (2017), untuk menentukan varietas padi gogo yang cocok di suatu daerah diperlukan beberapa pertimbangan antara lain: (a) kesesuaian agroekosistem (iklim, ketinggian tempat), (b) kesesuaian umur tanaman dengan curah hujan eksisting dan pola tanam, (c) kemampuan bertahan terhadap serangan hama dan penyakit, dan (d) produktivitas. Sedangkan Manzila dkk. (2020) menyebutkan bahwa Untuk meningkatkan produksi nasional, program pemuliaan padi di Indonesia difokuskan untuk menciptakan varietas dengan potensi produksi tinggi, tahan terhadap hama dan penyakit utama, memiliki umur yang pendek dan kualitas untuk dimakan yang baik.

Perkembangan VUB padi gogo relatif lebih lambat dibandingkan VUB padi sawah, hal ini dikarenakan petani secara berulang menanam varietas padi gogo lokal yang dihasilkannya sendiri (Sunanto dkk., 2020). Oleh karena itu VUB yang dihasilkan oleh pemerintah harus didiseminasikan secara kontinu untuk mewujudkan swasembada pangan melalui peningkatan produksi padi nasional. Badan Litbang Pertanian telah menghasilkan sebanyak 20 VUB padi gogo selama kurun waktu tahun 2003 hingga 2020. Arouna dkk. (2017) dalam penelitiannya, menemukan bahwa diseminasi varietas padi yang terus dilakukan dapat berkontribusi secara signifikan dalam pencapaian ketahanan pangan dan pengurangan kemiskinan di Afrika sub-Sahara. Beberapa VUB padi gogo yang sudah dihasilkan dan prospektif untuk dikembangkan disajikan pada Tabel 3.

Tabel 3. Beberapa VUB padi gogo prospektif di lahan kering

\begin{tabular}{|c|c|c|c|c|c|}
\hline No & VUB & $\begin{array}{l}\text { Potensi } \\
\text { produksi } \\
\text { (t/ha) }\end{array}$ & $\begin{array}{l}\text { Rata-rata } \\
\text { produksi } \\
(\mathrm{t} / \mathrm{ha})\end{array}$ & $\begin{array}{l}\text { Tahun } \\
\text { dilepas }\end{array}$ & Keunggulan \\
\hline 1 & Luhur 2 & 6,90 & 4,60 & 2018 & $\begin{array}{l}\text { Toleran kekeringan (vegetatif) dan } \\
\text { toleran keracunan aluminium }\end{array}$ \\
\hline 2 & Luhur 1 & 6,40 & 4,80 & 2018 & $\begin{array}{l}\text { Toleran kekeringan (vegetatif) dan agak } \\
\text { toleran keracunan aluminium }\end{array}$ \\
\hline 3 & Rindang 2 Agritan & 7,39 & 4,20 & 2017 & $\begin{array}{l}\text { Agak toleran naungan dan kekeringan, } \\
\text { sangat toleran keracunan aluminium } 40 \\
\text { ppm }\end{array}$ \\
\hline 4 & Rindang 1 Agritan & 6,97 & 4,62 & 2017 & $\begin{array}{l}\text { Toleran naungan, agak toleran } \\
\text { kekeringan, toleran keracunan } \\
\text { aluminium } 40 \mathrm{ppm}\end{array}$ \\
\hline 5 & Unsoed Parimas & 9,40 & 6,19 & 2017 & $\begin{array}{l}\text { Toleran kekeringan, toleran keracunan } \\
\text { aluminium } 40 \mathrm{ppm}\end{array}$ \\
\hline 6 & IPB 9G & 9,09 & 6,09 & 2017 & $\begin{array}{l}\text { Agak peka kekeringan, agak toleran } \\
\text { keracunan aluminium } 40 \mathrm{ppm}\end{array}$ \\
\hline 8 & Inpago 12 Agritan & 10,20 & 6,70 & 2017 & $\begin{array}{l}\text { Toleran kekeringan, toleran keracunan } \\
\text { aluminium }\end{array}$ \\
\hline 9 & Inpago 11 Agritan & 6,00 & 4,10 & 2015 & $\begin{array}{l}\text { Toleran kekeringan (vegetatuf), peka } \\
\text { keracunan aluminium } 60 \mathrm{ppm}\end{array}$ \\
\hline 10 & Inpago Lipigo 4 & 7,10 & 4,20 & 2013 & Toleran kekeringan \\
\hline 11 & Inpago 10 & 7,30 & 4,00 & 2013 & $\begin{array}{l}\text { Agak toleran kekeringan, agak toleran } \\
\text { keracunan aluminium } 60 \mathrm{ppm}\end{array}$ \\
\hline 12 & Inpago 9 & 8,40 & 5,20 & 2012 & $\begin{array}{l}\text { Agak toleran kekeringan, agak toleran } \\
\text { keracunan aluminium } 60 \mathrm{ppm}\end{array}$ \\
\hline
\end{tabular}

Sumber: PUSKATA, 2019; Sasmita dkk., 2019 


\section{Pengelolaan Tanaman Terpadu (PTT) Padi Gogo}

Tujuan PTT adalah untuk meningkatkan produktivitas tanaman dari segi hasil dan kualitas melalui penerapan teknologi yang cocok dengan kondisi setempat (spesifik lokasi) serta menjaga kelestarian lingkungan (Fitria \& Ali, 2014). Pendekatan PTT memperhitungkan keterpaduan antara tanaman dan sumber daya lainnya (Las et al., 1999). PTT padi gogo merupakan pendekatan budidaya padi gogo yang inovatif dan dinamis dalam rangka peningkatan produksi dan pendapatan petani dengan cara perakitan komponen teknologi partisipatif bersama petani. Komponen teknologi budidaya PTT padi gogo dapat dilihat secara ringkas disajikan pada Tabel 4.

Tabel 4. Komponen teknologi budidaya PTT padi gogo

\begin{tabular}{ll}
\hline \multicolumn{1}{c}{ Komponen Teknologi } & \multicolumn{1}{c}{ Keterangan } \\
\hline Pengolahan tanah & $\begin{array}{l}\text { Tanpa Olah Tanah (TOT) dan Olah Tanah Sempurna (OTS). } \\
\text { Penambahan bahan organik tanah, pembuatan teras gulud, } \\
\text { Kondidaya lorong (alley cropping), dan penerapan pola tanam }\end{array}$ \\
& $\begin{array}{l}\text { tumpang sari dengan tanaman lain. } \\
\text { Penggunaan VUB }\end{array}$ \\
Produktivitas tinggi, adaptif terhadap lingkungan (tanah dan iklim), \\
tahan terhadap hama dan penyakit.
\end{tabular}

Menurut (Toha, 2007) introduksi VUB yang cocok dengan penerapan komponen PTT padi gogo berdampak pada meningkatnya produksi, pendapatan petani, dan mencegah tanaman dari serangan blas. Selain itu pengembangan PTT padi gogo dengan memanfaatkan sisa tanaman sebagai mulsa juga dapat mengurangi penguapan air, mengurangi erosi, mengendalikan gulma, memperbaiki komposisi bahan organik pada tanah dan meningkatkan kesuburan tanah.

\section{Teknologi Larikan Gogo Super (Largo Super)}

Larikan Gogo Super (Largo Super) merupakan salah satu paket teknologi padi lahan kering hasil inovasi Badan Litbang Pertanian. Penerapan teknologi ini dapat dilakukan di lahan kering terbuka maupun ternaungi tanaman hutan atau perkebunan. Largo Super adalah teknologi padi lahan kering berbasis tanam jajar legowo (Jarwo) 2:1 yang penerapannya disertai dengan pemanfaatan mekanisasi pertanian.

Komponen penting dari teknologi Largo Super adalah: (1) penerapan sistem tanam jajar legowo 2:1, selain untuk meningkatkan populasi tanaman padi gogo, pola tanam Largo dapat mempermudah pemeliharaan saat penyiangan, penyemprotan gulma/rumput serta pemupukan karena berlorong; (2) pemanfaatan varietas unggul baru (VUB) padi gogo yang adaptif dan memiliki potensi produksi tinggi; (3) penggunaan pupuk hayati sebagai seed treatment dan pemupukan berimbang berdasarkan Perangkat uji Tanah Kering (PUTK); (4) penggunaan biodekomposer yang diberikan pada saat olah tanah; (5) penggunaan pestisida nabati untuk pengendalian Organisme Pengganggu Tanaman (OPT), hingga (6) pertanaman dengan Alat Tanam Benih Langsung (Atabela) dan panen menggunakan combine harvester (Gesha, 2018; Yartiwi dkk., 2020). Produktivitas padi gogo dengan penerapan teknologi Largo Super ini dapat mencapai rata-rata sebesar 7,9 t/ha. Capaian ini meningkat sebesar $3 \mathrm{t} / \mathrm{ha}$ dibandingkan dengan rata-rata produktivitas ditingkat petani selama ini (Balitbangtan, 2018). Sedangkan temuan penelitian Yartiwi dkk. (2020), produktivitas padi gogo dengan tiga perlakuan pemupukan menggunakan teknologi Largo Super di Kabupaten Bengkulu Tengah adalah sebesar $4,10-4,45$ t/ha.

\section{Prospek Pengembangan Padi Gogo Mendukung Lumbung Pangan Di Pulau Morotai}

Usahatani padi gogo di Pulau Morotai sebagian besar masih bersifat subsisten, dimana petani mengusahakan padi gogo untuk memenuhi kebutuhan pangan bagi rumah tangga petani. Walaupun sebagian petani menjual beras hasil usahatani padi gogo yang berlebih, namun komoditas padi gogo belum menjadi salah satu komoditas komersial secara luas. Hal ini merupakan cikal bakal peran lumbung pangan di tingkat rumah 
tangga petani. Usahatani padi gogo yang masih bersifat subsisten ini menyebabkan keengganan penangkar atau produsen benih memproduksi benih varietas unggul padi gogo (Hairmansis dkk, 2016). Upaya menyebarluaskan VUB dengan produksi hasil tinggi dan adaptif dengan lingkungan dapat dilakukan melalui diseminasi varietas yang kontinu. Hal ini dilakukan untuk menjamin ketersediaan varietas yang bisa menjadi pilihan bagi petani untuk melakukan pergiliran varietas. Upaya mewujudkan lumbung pangan di wilayah perbatasan Pulau Morotai diawali dengan membangun lumbung-lumbung pangan di tingkatan desa/wilayah.

Langkah operasional pengembangan padi gogo untuk meningkatkan produksi mendukung lumbung pangan di Pulau Morotai dapat dilakukan dengan upaya intensifikasi dan ekstensifikasi lahan padi gogo (Gambar 1). Intensifikasi dilakukan untuk mendorong peningkatan produksi, produktivitas dan peningkatan indeks pertanaman (IP). Penerapan inovasi teknologi budidaya padi gogo, seperti penerapan teknologi PTT padi gogo, Pengendalian Hama Terpadu (PHT), penggunaan VUB padi gogo, teknologi Largo Super serta usaha menjaga kelestarian tanah dan air dapat menjadi pilihan bijak untuk peningkatan produksi padi gogo dalam rangka mewujudkan lumbung pangan perbatasan di Pulau Morotai. Fungsi konservasi untuk menghambat terjadinya degradasi sumber daya lahan menjadi sangat penting mengingat usahatani di lahan kering pada umumnya lahan kurang subur dan peka terhadap erosi (Irawan, 2018). Peningkatan IP lahan padi gogo dengan rotasi tanaman padi gogo dengan tanaman palawija dapat juga mendorong peningkatan produksi tanaman pangan selain beras. Teknologi pilihan dapat diterapkan dengan mempertimbangkan dan menyesuaikan kondisi dan situasi setempat.

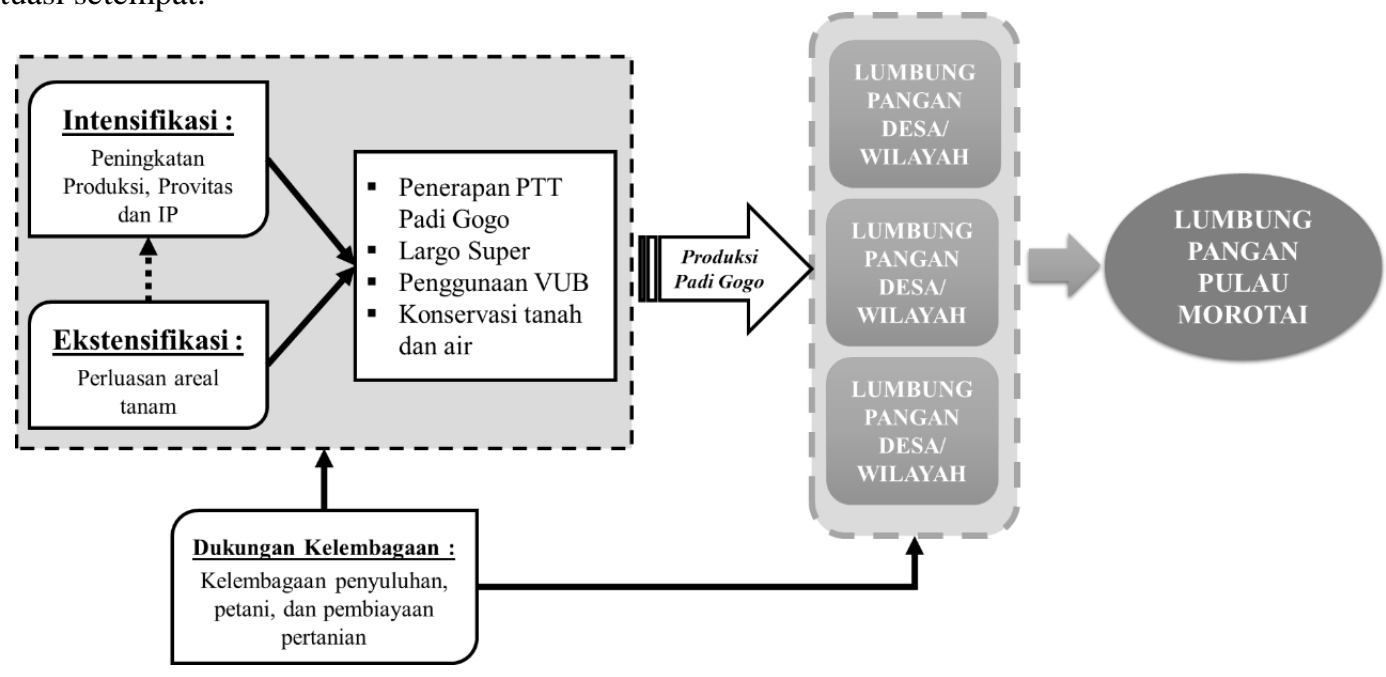

Gambar 1. Pola pengembangan padi gogo di wilayah perbatasan Pulau Morotai

Upaya ekstensifikasi atau perluasan lahan masih memungkinkan untuk dilakukan, karena masih ada peluang perluasan areal tanam padi gogo pada lahan kering yang memiliki potensi dan belum dimanfaatkan. Hal ini ditunjukkan dari adanya potensi lahan tadah hujan yang masih cukup luas, yaitu sebesar 6.000 hektar dan potensi lahan kering seluas 166.187 hektar. Sedangkan lahan tadah hujan yang sudah diusahakan adalah seluas 1.035 hektar (Tabel 5).

Peranan lahan kering akan semakin tinggi untuk menghasilkan bahan pangan ke depan karena secara teknis dan nonteknis pencetakan lahan sawah sulit untuk berkembang (Mulyani \& Agus, 2017). Lahan ini berpotensi besar mendukung upaya peningkatan produksi beras nasional dengan tersedianya varietas unggul padi yang adaptif pada lahan kering (Hairmansis et al., 2016). Pembersihan kayu, semak belukar dan alang-alang, disertai dengan teknik konservasi tanah dan air relatif mudah dilakukan dalam upaya perluasan lahan pertanian untuk pengembangan padi gogo (Sumarno dan Hidayat, 2007). Ekstensifikasi padi gogo diarahkan juga untuk menerapkan inovasi teknologi budidaya padi gogo yang sudah tersedia, sehingga produksi yang dihasilkan akan optimal. Selain itu, ke depannya lahan tersebut diarahkan untuk diusahakan secara intensif untuk produksi pangan.

Tabel 5. Potensi lahan tadah hujan dan lahan kering di Pulau Morotai

\begin{tabular}{cccccc}
\hline No & Kecamatan & $\begin{array}{c}\text { Lahan tadah hujan } \\
\text { potensial (ha) } * *\end{array}$ & $\begin{array}{c}\text { Lahan tadah } \\
\text { hujan } \\
\text { diusahakan (ha) } \\
* *\end{array}$ & $\begin{array}{c}\text { Lahan tadah hujan } \\
\text { akan } \\
\text { dikembangkan } \\
\text { (ha) ** }\end{array}$ & $\begin{array}{c}\text { Lahan kering } \\
\text { potensial } \\
\text { (ha) } *\end{array}$ \\
\hline 1 & Morotai Selatan & 2.000 & 200 & 200 & 35.425 \\
2 & Morotai Timur & 1.000 & 140 & 140 & 30.227 \\
\hline
\end{tabular}

Proceedings homepage: https://conferenceproceedings.ump.ac.id/index.php/pspfs/issue/view/9 


\begin{tabular}{|c|c|c|c|c|c|}
\hline 3 & $\begin{array}{l}\text { Morotai Selatan } \\
\text { Barat }\end{array}$ & 1.000 & 150 & 150 & 39.243 \\
\hline 4 & Morotai Utara & 1.000 & 445 & 445 & 31.417 \\
\hline 5 & Morotai Jaya & 1.000 & 100 & 100 & 29.875 \\
\hline & Jumlah & 6.000 & 1.035 & 1.035 & 166.187 \\
\hline
\end{tabular}

Sumber: * BPS Kabupaten Pulau Morotai, 2012

** BPS Kabupaten Pulau Morotai, 2019

Dukungan inovasi kelembagaan juga sangat diperlukan guna menciptakan kondisi keberlanjutan program dan kegiatan dalam upaya mewujudkan lumbung pangan di Pulau Morotai. Inovasi kelembagaan ditujukan untuk peningkatan SDM petani dan penyuluh pertanian. Peningkatan kinerja kelembagaan penyuluhan dan SDM penyuluh untuk mendampingi dan mengawal petani padi gogo. Penguatan kelembagaan petani padi gogo melalui pembinaan kelembagaan Poktan dan Gapoktan untuk meningkatkan SDM petani. Selain peningkatan SDM petani dalam budidaya padi gogo, perlu juga ditumbuhkan penangkar-penangkar benih padi gogo secara lokal baik formal maupun informal yang mampu berperan memproduksi benih VUB padi gogo yang diinginkan dan dibutuhkan oleh petani setempat. Kelembagaan petani berperan multifungsi, mulai dari pra produksi, produksi, panen dan pascapanen hingga pemasaran hasil dilakukan secara kolektif dan terencana.

Dukungan kelembagaan pembiayaan pertanian bagi petani juga menjadi penting saat usaha yang dirintis oleh petani menjadi semakin besar. Selain upaya mendorong produksi pangan utama berupa beras, produksi tanaman pangan lokal selain beras juga bisa menjadi sumber pangan lokal masyarakat yang dapat diandalkan. Kebijakan pembangunan pertanian dan ketahanan pangan melalui pengembangan tanaman pangan khususnya beras harus beriringan dengan upaya diversifikasi pangan lokal untuk memenuhi kebutuhan kalori, protein, vitamin, dan mineral (Andani, 2008).

\section{KESIMPULAN}

Usahatani padi gogo di Pulau Morotai sebagian besar masih bersifat subsisten. Hal ini merupakan gambaran lumbung pangan di tingkat rumah tangga petani sudah ada sejak lama. Potensi dan peluang pengembangan padi gogo mendukung lumbung pangan di wilayah perbatasan Pulau Morotai masih sangat prospektif. Dukungan sumber daya lahan kering potensial untuk perluasan areal tanam serta inovasi teknologi yang sudah dihasilkan dapat menjadi titik ungkit peningkatan produksi dan produktivitas padi gogo. Walaupun usahatani padi gogo diusahakan petani secara subsisten dengan tingkat produktivitas yang masih rendah, namun berdasarkan analisis finansial usahatani masih layak untuk dikembangkan bahkan ditingkatkan.

Upaya pengembangan padi gogo dimulai dengan membangun lumbung-lumbung pangan di tingkatan desa/wilayah sebagai pijakan awal mewujudkan lumbung pangan di wilayah perbatasan Pulau Morotai. Langkah operasional untuk menaikkan tingkat produksi dan membangun lumbung pangan di desa/wilayah dapat dilakukan melalui upaya intensifikasi lahan pertanian, yaitu melalui pemanfaatan inovasi teknologi budidaya (PTT padi gogo, Largo Super), penggunaan VUB padi gogo, serta peningkatan IP. Upaya ekstensifikasi pertanian ditempuh dengan penambahan luas areal tanam padi gogo pada lahan kering potensial yang belum termanfaatkan. Kedua upaya tersebut disertai dengan penerapan konservasi tanah dan air untuk menjaga keberlanjutan produksi padi gogo. Dukungan peran dan fungsi kelembagaan penyuluhan, petani, dan pembiayaan pertanian diperlukan guna mempercepat terwujudnya lumbung pangan desa/wilayah untuk membangun pondasi lumbung pangan di wilayah perbatasan Pulau Morotai.

\section{UCAPAN TERIMA KASIH}

Ucapan terimakasih disampaikan kepada Bapak Murid Kaucil selaku Koordinator BPP Morotai Timur dan pihak Dinas Pertanian Kabupaten Pulau Morotai yang telah memberikan pendampingan dan informasi kepada penulis selama melaksanakan kegiatan survei dan wawancara di lapangan.

\section{DAFTAR PUSTAKA}

Akmal, \& Nazarudin. (2016). Petunjuk Teknis Budi Daya Padi Gogo Di Lahan Kering. Balai Pengkajian Teknologi Pertanian Sumatera Utara.

Andani, A. (2008). Analisis Prakiraan Produksi dan Konsumsi Beras Indonesia. AGRISEP2, 8(1), 1-18. https://doi.org/https://doi.org/10.31186/ jagrisep.7.2.1-18.

Arouna, A., Lokossou, J. C., Wopereis, M. C. S., Bruce-Oliver, S., \& Roy-Macauley, H. (2017). Contribution of improved rice varieties to poverty reduction and food security in sub-Saharan Africa. Global Food Security, 14, 54-60. https://doi.org/https://doi.org/10.1016/j.gfs.2017.03.001.

Balitbangtan. (2008). Pengelolaan Tanaman Terpadu (PTT) Padi Gogo. Badan Penelitian dan Pengembangan Pertanian. 
Balitbangtan. (2018). Largo Super Mengoptimalkan Lahan Kering. http://www.litbang.pertanian.go.id/infoaktual/3176/

BPS. (2018). Kajian Konsumsi Bahan Pokok 2017 (06330.1904).

BPS Kabupaten Pulau Morotai. (2012). Kabupaten Pulau Morotai Dalam Angka 2012 (82070.1101).

BPS Kabupaten Pulau Morotai. (2014). Pulau Morotai Dalam Angka 2014 (82070.1101).

BPS Kabupaten Pulau Morotai. (2017). Kabupaten Pulau Morotai Dalam Angka 2017 (82070.1701; 25031317).

BPS Kabupaten Pulau Morotai. (2019). Kabupaten Pulau Morotai Dalam Angka 2019 (82070.1701; 25031317).

BPS Provinsi Maluku Utara. (2017). Provinsi Maluku Utara Dalam Angka 2017 (82560.1707; 2356-0592).

Budianta, A. (2010). Pengembangan Wilayah Perbatasan Sebagai Upaya Pemerataan Pembangunan Wilayah di Indonesia. $\quad$ SMARTek, $\quad 8(1), \quad 72-82$. http://jurnal.untad.ac.id/jurnal/index.php/SMARTEK/article/view/628/546.

Cristanto, J., Riasasi, W., \& Fathonah, D. S. (2014). Overview Kebijakan Pengelolaan Perbatasan Negara Kesatuan Republik Indonesia (NKRI). In Pengelolaan Wilayah Perbatasan NKRI (pp. 1-38). Gadjah Mada University Press.

Fitria, E., \& Ali, M. N. (2014). Kelayakan Usaha Tani Padi Gogo Dengan Pola Pengelolaan Tanaman Terpadu (PTT) Di Kabupaten Aceh Besar, Provinsi Aceh. Widyariset, 17(3), 425-434.

Gesha. (2018). Atabela, Komponen Penting Largo Super. Tabloid Sinartani.Com. https://tabloidsinartani.com/detail/indeks/tekno-lingkungan/6234-Atabela-Komponen-Penting-LargoSuper.

Gray, C., Simanjuntak, P., Sabur, L. K., Maspaitella, P. F. ., \& Varley, R. C. . (1992). Pengantar Evaluasi Proyek (Edisi II). PT. Gramedia Pustaka Utama.

Hairmansis, A., Kustianto, B., Lubis, E., \& Suwarno. (2008). Increasing Genetic Diversity through Participatory Varietal Selection of Upland Rice in Lampung. Penelitian Pertanian Tanaman Pangan, 27(1), 9-12.

Hairmansis, A., Yullianida, Supartopo, \& Suwarno. (2016). Pemuliaan Padi Gogo Adaptif pada Lahan Kering. Iptek Tanaman Pangan, 11(2), 95-106.

Hasmi, I., \& Widyantoro. (2017). Pengaruh Pemupukan NPK Majemuk Dan Urea Terhadap Pertumbuhan Dan Hasil Padi Gogo. Seminar Nasional 2016 Buku 1, 67-74.

Irawan, B. (2018). Memperkuat Usahatani Rakyat Berbasis Lahan Kering. In E. Pasandaran, M. Syakir, \& M. P. Yufdy (Eds.), Sinergi Inovasi Sumber Daya dan Kelembagaan Menuju Kesejahteraan Petani (pp. 3994). IAARD Press.

Juhandi, D., \& Enre, A. (2019). Kebijakan Upsus Pajale: Mampukah Menambah Provinsi Basis Produksi Pajale? Habitat, 30(3), 123-131. https://doi.org/10.21776/ub.habitat.2019.030.3.15

Kementerian Pertanian. (2018). Statistik Pertanian 2018. Pusat Data dan Sistem Informasi Pertanian.

Las, I., Makarim, A. K., Sumarno, Purba, S., Mardiharini, M., \& Kartaatmadja, S. (1999). Pola IP Padi 300: Konsepsi dan Prospek Implementasi Sistem Usaha Pertanian Berbasis Sumber Daya. Badan Penelitian dan Pengembangan Pertanian.

Leta, J., Machado, R. d. N., \& Canchumani, R. M. L. (2019). Scientific Collaboration Among BRICS: Trends and Priority Areas. In W. Glanzel, H. F. Moed, U. Schmoch, \& M. Thelwall (Eds.), Springer Handbook of Science and Technology Indicators (pp. 485-504). Springer. https://doi.org/https://doi.org/10.1007 1978-3-030-02511-3.

Malik, A. (2017). Prospek Pengembangan Padi gogo: Perspektif Kebijakan Dan Implementasi Di Lapangan. IAARD Press.

Manzila, I., Priyatno, T. P., Lestari, P., \& Mastur. (2020). Improvement of Rice Resistant to Important Rice Virus Diseases with The Benefit of Indonesian Local Varieties. In M. Sabran, P. Lestari, D. Satyawan, T. Hadiarto, Mastur, \& R. T. Terryana (Eds.), Boosting The Big Data of Plant With Digital Identifiers (1st ed., pp. 131-146). IAARD Press. 
Marwasta, D. (2016). Pendampingan Pengelolaan Wilayah Perbatasan Di Indonesia: Lesson Learned Dari KKN-PPM UGM Di Kawasan Perbatasan. Indonesian Journal of Community Engagement, 01(02), 204216.

Maulana, M. (2004). Peranan Luas Lahan, Intensitas Pertanman dan Produktifitas Sebagai Sumber Pertumbuhan Padi Sawah di Indonesia 1980 - 2001. Agro Ekonomi, 22(1), 74-95.

Mulyani, A., \& Agus, F. (2017). Kebutuhan Dan Ketersediaan Lahan Cadangan Untuk Mewujudkan Cita-Cita Indonesia Sebagai Lumbung Pangan Dunia Tahun 2045. Analisis, 15(1), 1-17. https://doi.org/http://dx.doi.org /10.21082/akp.v15n1.2017.1-17.

Normansyah, D., Rochaeni, S., \& Humaerah, A. D. (2014). Analisis Pendapatan Usahatani Sayuran Di Kelompok Tani Jaya, Desa Ciaruteun Ilir, Kecamatan Cibungbulang, Kabupaten Bogor. Jurnal Agribisnis, 8(1), 29-44.

PUSKATA. (2019). Varietas Unggul Padi Gogo. Pusat Perpustakaan dan Penyebaran Teknologi Pertanian.

Rachmat, M., Budhi, G. S., Supriyati, \& Sejati, W. K. (2011). Lumbung Pangan Masyarakat: Keberadaan Dan Perannya Dalam Penanggulangan Kerawanan Pangan. Forum Penelitian Agro Ekonomi, 29(1), 43-53. https://doi.org/https://doi.org/10.21082/fae.v29n1.2011.43-53.

Rope, R. (2013). Karakteristik Sistem Pertanian Alami (Natural Farming) Padi Ladang di Kecamatan Morotai Timur. Agrikan: Jurnal Ilmiah Agribisnis Dan Perikanan, 6(1), 37. https://doi.org/10.29239/j.agrikan.6.1.37-51.

Saleh, Y., Aji, H. B., \& Zainiyah, W. (2017). Petunjuk Teknis: Teknologi Budidaya Pengelolaan Tanaman Terpadu ( PTT ) Padi Gogo di Pulau Morotai. Balai Pengkajian Teknologi Pertanian Maluku Utara.

Sasmita, P., Satoto, Rahmini, Agustiani, N., Handoko, D. D., Suprihanto, Guswara, A., \& Suharna. (2019). Deskripsi Varietas Unggul Baru Padi. Balai Besar Penelitian Tanaman Padi.

Soekartawi. (1995). Analisis Usahatani. Universitas Indonesia Press.

Sujitno, E., \& Dianawati, M. (2017). Peningkatan Produksi Padi Gogo Di Lahan Kering Kabupaten Garut Jawa Barat Dengan Menggunakan Pupuk Organik. Seminar Nasional 2016 Buku 1, 175-180.

Sujitno, E., \& Kurnia. (2014). Potensi Hasil Varietas Unggul Baru Padi Gogo Pada Lahan Kering Menunjang Peningkatan Produksi Beras Nasional di Kabupaten Garut. AGROTROP, 4(2), 133-138.

Sulaiman, A. A., Las, I., Subagyono, K., Alihamsyah, T., \& Hermanto. (2018). Membangun Lumbung Pangan Di Wilayah Perbatasan: Sinergi Merintis Ekspor Pangan di Wilayah Perbatasan NKRI (A. Suryana, Hermanto, \& R. Hendayana (eds.); Edisi II).

Sulaiman, A. A., Simatupang, P., Kariyasa, I. K., Subagyono, K., Las, I., Jamal, E., Hermanto, Syahyuti, Sumaryanto, \& Suwandi. (2017). Sukses Swasembada Indonesia Menjadi Lumbung Pangan Dunia 2045 (T. Sudaryanto, A. Suryana, \& Hermanto (eds.)). IAARD Press.

Sumarno, \& Hidayat, J. R. (2007). Perluasan Areal Padi Gogo sebagai Pilihan untuk Mendukung Ketahanan Pangan Nasional. Iptek Tanaman Pangan, 2(1), 26-40.

Sunanto, Wahid, A., \& Yuniarsih, E. T. (2020). Respon Petani Terhadap Varietas Unggul Baru Padi Gogo di Sulawesi Selatan. Jurnal Pengkajian Dan Pengembangan Teknologi Pertanian, 23(1), 119-127.

Syarief, R., Sumardjo, \& Fatchiya, A. (2014). Kajian Model Pemberdayaan Ketahanan Pangan di Wilayah Perbatasan Antar Negara. Jurnal Ilmu Pertanian Indonesia (JIPI), 19(1), 9-13.

Toha, H. M. (2007). Peningkatan Produktivitas Padi Gogo melalui Penerapan Pengelolaan Tanaman Terpadu dengan Introduksi Varietas Unggul. Penelitian Pertanian Tanaman Pangan2, 26(3), 180-187.

Yartiwi, Calista, I., Yahumri, \& Musaddad, D. (2020). Analisa Usaha Tani Padi Gogo Dengan Teknologi Larikan Gogo Pada Beberapa Dosis Pemupukan Di Kabupaten Bengkulu Tengah. Seminar Nasional Kesiapan Sumber Daya Pertanian Dan Inovasi Spesifik Lokasi Memasuki Era Industri 4.0, 655-660.

Yuniarti, S. (2015). Respon pertumbuhan dan hasil varietas unggul baru (VUB) padi gogo di Kabupaten Pandeglang, Banten. PROS SEM NAS MASY BIODIV INDON, 1(4), 848-851. https://doi.org/10.13057/psnmbi/m010432. 